\title{
Investigation of Epstein-Barr Virus and Parvovirus B19 DNA in Allogeneic Stem Cell Transplant Patients
}

\section{Allojenik Kök Hücre Transplantasyonu Yapilan Hastalarda Epstein-Barr Virus ve Parvovirus B19 DNA Araştırılması}

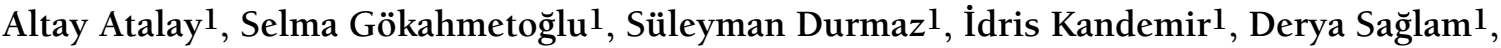 \\ Leylagül Kaynar2, Bülent Eser², Mustafa Çetin² ${ }^{2}$, Hüseyin Kılıç1 \\ ${ }^{1}$ Erciyes University Faculty of Medicine, Department of Clinical Microbiology, Kayseri, Turkey \\ ${ }^{2}$ Erciyes University Faculty of Medicine, Department of Hematology, Kayseri, Turkey
}

\begin{abstract}
:
Objective: We aimed to investigate posttransplant Epstein-Barr virus (EBV) and parvovirus B19 DNA in allogeneic stem cell transplant patients between 2009 and 2010.

Materials and Methods: Forty-five adult patients in whom allogeneic stem cell transplantation was performed between April 2009 and November 2010 in the Erciyes University Faculty of Medicine, Department of Internal Medicine, Division of Hematology and Oncology, were included in the study. EBV and parvovirus B19 DNA positivity was investigated by using realtime polymerase chain reaction technique in 135 plasma samples obtained after transplantation at between 1 and 6 months. Pretransplant serological markers of EBV and parvovirus B19 were provided from patient files.

Results: In $32(71.1 \%)$ of the patients, EBV antibodies in the pretransplantation period were as follows: anti-EBNA-1 IgG (+), VCA IgM (-), and VCA IgG (+). In 2 patients $(4.45 \%)$, these antibodies were as follows: anti-EBNA-1 IgG (+), VCA IgM (-), and VCA IgG (-). In 1 patient (2.2\%), they were as follows: anti-EBNA-1 IgG (-), VCA IgM (-), and VCA IgG (+). EBV serological markers were negative in $2(2.2 \%)$ out of 45 patients before transplantation. There was low DNA positivity ( $<600 \mathrm{copies} / \mathrm{mL})$ in 4 patients (8.9\%), and VCA IgM was negative and VCA IgG was positive in these same 4 patients. In spite of low viral load, there were no symptoms related to EBV, and posttransplant lymphoproliferative disorder (PTLD) did not occur. While in 44 (99.7\%) of 45 patients parvovirus B19 IgM was negative and IgG was positive, parvovirus B19 IgM was positive and IgG was negative in 1 (2.3\%) patient. Parvovirus B19 DNA was not identified in any of the samples obtained from these 45 patients.

Conclusion: In this study, EBV and parvovirus B19 DNA were investigated in allogeneic stem cell transplant patients. None of the patients developed PTLD and parvovirus B19 DNA positivity was not detected. However, this issue needs to be further evaluated in prospective, multicenter studies with larger series of patients.
\end{abstract}

Key Words: Epstein-Barr virus, Parvovirus B19, Allogeneic stem cell transplantation, Real-time PCR

\section{Özet:}

Amaç: Bu çalışmada, 2009-2010 yılları arasında allojenik kök hücre transplantasyonu (AKHT) yapılan hastalarda transplantasyon sonrası EBV ve parvovirus B19 DNA araştırılması amaçlandı.

Address for Correspondence: Altay ATALAY, M.D.,

Erciyes University Faculty of Medicine, Department of Clinical Microbiology, Kayseri, Turkey

Phone: +90 35220766 66-23385 E-mail: altayatalay@gmail.com

Received/Geliş tarihi ： March 27, 2012

Accepted/Kabul tarihi : March 22, 2013 
Gereç ve Yöntemler: Bu çalışmaya Erciyes Üniversitesi Tıp Fakültesi İç Hastalıkları Anabilim Dalı HematolojiOnkoloji Bilim Dalı'nda Nisan 2009-Kasım 2010 tarihleri arasında AKHT yapılmış 45 erişkin hasta dahil edildi. Hastaların transplantasyon sonrası 1-6. aylar arasında alınan toplam 135 plazma örneğinde EBV ve parvovirus B19 DNA varlığı gerçek zamanlı PCR yöntemi ile araştırıldı. Hastalara ait transplantasyon öncesi EBV ve parvovirus B19 serolojik göstergeleri hasta dosyalarından temin edildi.

Bulgular: AKHT öncesi serolojik göstergelerde, 45 hastanın 32'sinde $(\% 71,1)$ EBNA-1 IgG (+), VCA IgM (-) ve VCA IgG (+) idi. İki hastada (\%4,45) EBNA-1 IgG (+), VCA IgM (-) ve VCA IgG (-), bir hastada (\%2,2) EBNA-1 IgG (-), VCA IgM (-) ve VCA IgG $(+)$ ve $2(\% 4,45)$ hastada tüm serolojik göstergeler negatifti. Transplantasyon sonrası düşük EBV DNA pozitifliği $(<600$ kopya/mL) $4(\% 8,9)$ hastada saptand, bu hastaların hepsinde VCA IgM negatif, VCA IgG pozitif bulundu. Düşük viral yüke rağmen bu hastalarda EBV ilişkili semptom görülmemiş ve PTLD gelişmemiştir. Kırk beş hastanın 44'ünde (\%97,7) parvovirus B19 IgM negatif, IgG pozitif iken sadece bir hastada $(\% 2,3)$ parvovirus B19 IgM pozitif, IgG negatifti. Kırk beş hastadan elde edilen örneklerin hiçbirinde parvovirus B19 DNA saptanmadı.

Sonuç: Bu çalışmada AKHT hastalarında EBV ve parvovirus B19 DNA araştırıldı. Hastaların hiçbirinde PTLD gelişmezken parvovirus B19 DNA pozitifliği de saptanmadı. Ancak bu konunun aydınlatılmasında daha geniş hasta serileri ile yapılan, prospektif, çok merkezli ileri çalışmalara ihtiyaç vardır.

Anahtar Sözcükler: Epstein-Barr virüs, Parvovirus B19, Allojenik kök hücre transplantasyonu, Gerçek zamanlı PCR

\section{Introduction}

Allogeneic stem cell transplantation (ASCT) has been applied as a treatment option in an ever-increasing manner in various malignancies and hematological disorders for 40 years [1]. Posttreatment infections and graft-versushost disease are the most common problems in ASCT [2]. Cytomegalovirus (CMV) is still the most important virus that infects hematopoietic stem cell and solid organ transplant recipients. However, the list of viruses that infect these patients and cause severe morbidity and mortality gets longer each day [3].

The Epstein-Barr virus (EBV) is a member of the family Herpesviridae. EBV infects almost all of the adult population in the world and stays persistent throughout life, as do all the other herpes viruses. Bone marrow transplant recipients carry a 4- to 7-fold increased risk of cancer compared to the normal population. Severe immune deficiency is observed within the first year after transplantation. Posttransplant lymphoproliferative disorder (PTLD) mostly appears in this period, and especially in the first 5 months. The mean PTLD incidence is $1 \%$ in allogeneic SCT recipients [4,5]. Human parvovirus (PV) B19 is the smallest DNA virus known so far, a nonenveloped microorganism of 18-26 $\mathrm{nm}$ in size [6]. Chronic PV B19 infections are described in many patients following stem cell transplantation. The infections encountered during chemotherapy in this patient group may mimic leukopenic relapses or therapy-induced cytopenias, and thus may cause misdiagnoses, unnecessary blood transfusions, and premature abortion of treatment $[7,8]$. Therefore, rapid diagnosis and treatment of PV B19 infections is very important in this patient group.

The aim of this study was to investigate the occurrence of EBV-DNAemia after ASCT and its duration and magnitude, and to correlate these results with the appearance of
EBV-driven PTLD. At the same time, another aim was to investigate the occurrence, duration, and magnitude of PV B19-DNAemia after ASCT.

\section{Materials and Methods}

Forty-five adult patients who underwent ASCT at the Erciyes University Medical Faculty, Department of Internal Medicine, Division of Hematology and Oncology, between April 2009 and November 2010 were included in the study. The presence of EBV and PV B19 DNA were investigated in a total of 135 plasma samples via real-time polymerase chain reaction (PCR) in the posttransplantation period (3 samples from each patient for EBV between the first and sixth months; 3 samples for each patient for PV B19 in the first, second, and third months). Two milliliters of blood samples with ethylenediaminetetraacetic acid was taken from all patients for the investigations of EBV and PV B19 DNAs. Plasma was separated following centrifugation and kept at $-70^{\circ} \mathrm{C}$ until analyses. DNA extraction from blood plasma was performed by the recommendations of the manufacturer using the EZl advanced virus kit (QIAGEN, Germany). DNAs were analyzed via real-time PCR using the EBV RG PCR kit (QIAGEN) for EBV and PV B19 RG PCR kit (QIAGEN) for PV B19. Extracted DNA $(10 \mu \mathrm{L})$ was added to the plaques containing $15 \mu \mathrm{L}$ of reaction mixture. An internal control of approximately $0.25 \mu \mathrm{L}$ was added to the reaction mixture. PCR was conducted for $10 \mathrm{~min}$ at $95^{\circ} \mathrm{C}$, and then 45 cycles were repeated as follows: 1 cycle was composed of $15 \mathrm{~s}$ at $95^{\circ} \mathrm{C}, 30 \mathrm{~s}$ at $55^{\circ} \mathrm{C}$, and $20 \mathrm{~s}$ at $72^{\circ} \mathrm{C}$. Amplification was performed in a Rotor-Gene 6000 instrument (Corbett Research, Australia). The quantitation range of the realtime PCR test for EBV was $600-600.000$ copies $/ \mathrm{mL}$, and the analytic sensitivity was 157 copies/mL. For PV B19, the quantitation range was $1500-15.000 .000$ copies $/ \mathrm{mL}$ and the analytic sensitivity was 30 copies/mL. The serological EBV 
and PV B19 indicators of patients were obtained from the patient files. The ethics committee approved this study.

\section{Statistical}

Statistical analysis was performed using SPSS 13.0. Categorical variables are presented as numbers and percentages, and continuous variables are presented as mean \pm SD or median.

\section{Results}

The demographical characteristics of patients included in the study are shown in Table 1. HLA-matching status for ASCT was full-match in 35 patients and all of the allogeneic transplant donors were related. According to the pre-ASCT serological indicators of the patient files, 32 of 45 patients (71.1\%) were EBNA-1 IgG (+), VCA IgM (-), and VCA IgG $(+)$. Two patients $(4.45 \%)$ were EBNA-1 IgG (+), VCA IgM $(-)$, and VCA IgG (-); 1 patient (2.2\%) was EBNA-1 IgG $(-)$, VCA IgM (-), and VCA IgG (+); and 2 patients (4.45\%) were serologically negative for all indicators. EBNA-1 $\operatorname{IgG}$ results could not be obtained for $8(17.8 \%)$ patients. Six of these 8 patients (75\%) were VCA IgM (-) and VCA IgG $(+)$, whereas 2 (25\%) were VCA IgM (-) and VCA IgG $(-)$. EBV-specific antibody EA was negative in 34 patients (75.5\%) and positive in 1 patient (2.2\%). The EA-positive patient was VCA IgM (-), VCA IgG (+), and EBNA-1 $\operatorname{IgG}(+)$. EA results could not be obtained for 10 patients (22.3\%). EBV DNA was positive $(<600$ copies $/ \mathrm{mL})$ in 4 patients (8.9\%), and they were all VCA IgM (-) and VCA IgG (+). EBV DNA positivity of these patients belonged to the posttransplantation third month in 2 patients, fifth month in 1 patient, and sixth month in 1 patient (Table 2). No EBV-related symptom or PTLD was observed in these patients despite the low viral load. We wanted to follow the results of all 4 patients that had low EBV viral load, but 1 of them died and 1 went to another hospital for treatment. We were able to check the results of the other 2 patients, and EBV DNA was found to be negative.

In $44(97.7 \%)$ of 45 patients, PV B19 IgM was negative and IgG was positive, whereas in only 1 patient (2.3\%), PV B19 IgM was positive and IgG was negative. No PV B19 DNA was observed in the samples obtained from these 45 patients. EBV and PV B19 serology of the donors and patients included in the study are shown in Table 3.

\section{Discussion}

Determining a patient's risk factors concerning posttransplantation viral infection development may be possible by detecting the virological situations of both the

Table 1. Demographic characteristics of patients.

\begin{tabular}{|l|l|}
\hline Patient characteristics & $\mathbf{n} \pm$ SD \\
\hline Age (years) & $33.3 \pm 11.3$ \\
\hline Sex & $\mathbf{n}(\%)$ \\
\hline Female & $20(44.4)$ \\
\hline Male & $25(55.6)$ \\
\hline Pre-ASCT diagnosis & $\mathbf{n}(\%)$ \\
\hline Acute myeloid leukemia & $21(46.8)$ \\
\hline Aplastic anemia & $12(26.7)$ \\
\hline Myelofibrosis & $3(6.7)$ \\
\hline Chronic myeloid leukemia & $2(4.4)$ \\
\hline Paroxysmal nocturnal hemoglobinuria & $2(4.4)$ \\
\hline Non-Hodgkin lymphoma & $1(2.2)$ \\
\hline Hodgkin lymphoma & $1(2.2)$ \\
\hline Multiple myeloma & $1(2.2)$ \\
\hline
\end{tabular}

Table 2. Demographic characteristics, serological indicators, and positivity times of patients with positive EBV DNA.

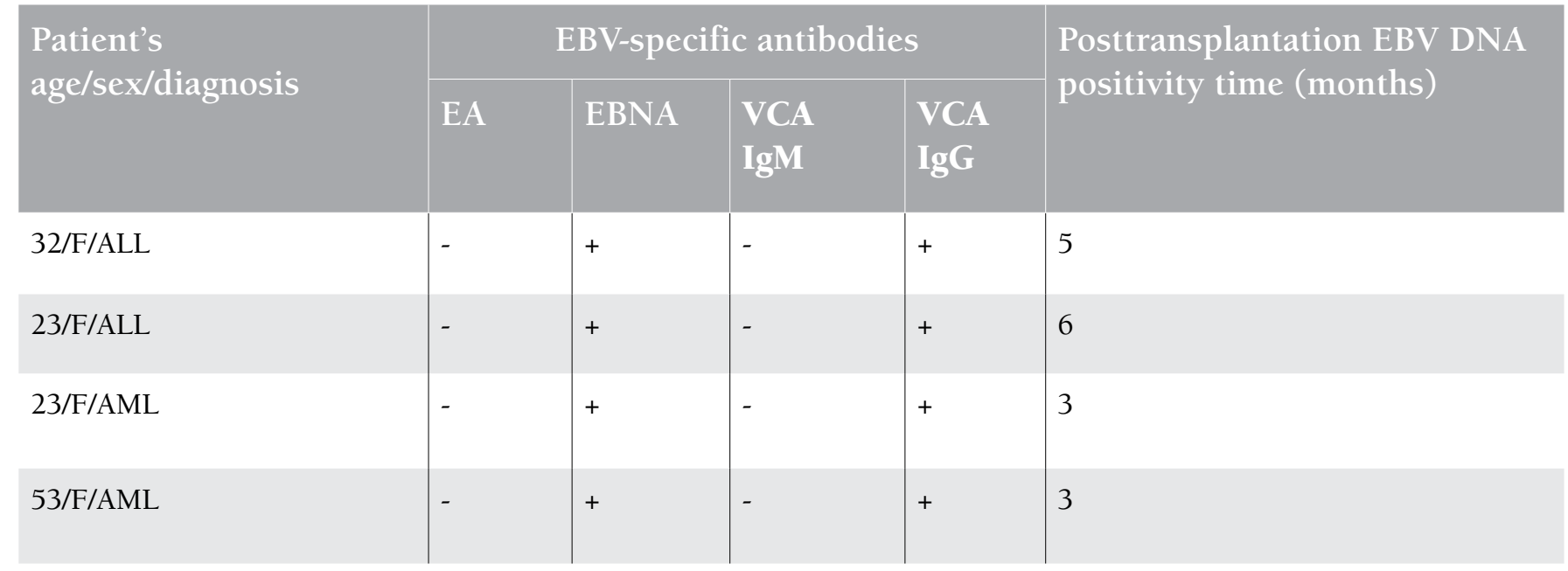

F: Female, EA: early antigen, EBNA: Epstein-Barr nuclear antigen, VCA: viral capsid antigen, ALL: acute lymphocytic leukemia, AML: acute myeloid leukemia 
Table 3. EBV and PV B19 serology of the donors and patients.

\begin{tabular}{|c|c|c|c|c|c|c|c|c|c|c|c|c|}
\hline \multirow[b]{2}{*}{ Patient no. } & \multicolumn{8}{|c|}{ EBV-specific antibodies } & \multicolumn{4}{|c|}{$\begin{array}{c}\text { Parvovirus B19-specific } \\
\text { antibodies }\end{array}$} \\
\hline & $\begin{array}{l}\text { D } \\
\text { EA }\end{array}$ & $\begin{array}{l}\mathbf{P} \\
\mathbf{E A}\end{array}$ & $\begin{array}{l}\text { D } \\
\text { EBNA }\end{array}$ & $\begin{array}{l}\text { P } \\
\text { EBNA }\end{array}$ & $\begin{array}{l}\text { D } \\
\text { VCA } \\
\text { IgM }\end{array}$ & $\begin{array}{l}\text { P } \\
\text { VCA } \\
\text { IgM }\end{array}$ & $\begin{array}{l}\text { D } \\
\text { VCA } \\
\text { IgG }\end{array}$ & $\begin{array}{l}\text { P } \\
\text { VCA } \\
\text { IgG }\end{array}$ & $\begin{array}{l}\text { D } \\
\operatorname{IgM}\end{array}$ & $\begin{array}{l}\mathbf{P} \\
\operatorname{Ig} M\end{array}$ & $\begin{array}{l}\text { D } \\
\operatorname{Ig} G\end{array}$ & $\begin{array}{l}\mathbf{P} \\
\operatorname{IgG}\end{array}$ \\
\hline 1 & NA & NA & NA & NA & NA & - & NA & + & - & - & + & + \\
\hline 2 & NA & - & NA & NA & - & - & + & + & - & - & + & + \\
\hline 3 & - & - & + & + & - & - & + & + & - & - & + & + \\
\hline 4 & - & - & + & + & - & - & + & + & - & - & + & + \\
\hline 5 & - & - & + & + & - & - & + & + & - & - & + & + \\
\hline 6 & - & - & - & - & - & - & + & + & - & - & + & + \\
\hline 7 & - & - & + & + & - & - & + & + & - & - & + & + \\
\hline 8 & - & - & + & + & - & - & + & + & - & - & + & + \\
\hline 9 & - & - & + & - & - & - & + & - & - & - & + & + \\
\hline 10 & - & NA & + & NA & - & - & + & + & - & - & + & + \\
\hline 11 & NA & - & NA & + & NA & - & NA & + & NA & + & NA & - \\
\hline 12 & - & - & + & + & - & - & + & + & - & - & + & + \\
\hline 13 & - & - & + & + & - & - & + & + & - & - & + & + \\
\hline 14 & NA & - & NA & + & NA & - & NA & + & NA & - & NA & + \\
\hline 15 & - & - & + & + & - & - & + & + & - & - & + & + \\
\hline 16 & - & - & + & + & - & - & + & + & - & - & + & + \\
\hline 17 & NA & - & NA & + & NA & - & NA & - & - & - & + & + \\
\hline 18 & - & NA & + & + & - & - & + & + & - & - & + & + \\
\hline 19 & NA & - & NA & + & NA & - & NA & + & - & - & + & + \\
\hline 20 & NA & - & NA & + & - & - & + & + & - & - & + & + \\
\hline 21 & - & - & + & + & - & - & + & + & - & - & + & + \\
\hline 22 & - & - & + & + & - & - & + & + & - & - & + & + \\
\hline 23 & - & - & + & + & - & - & + & + & - & - & + & + \\
\hline 24 & - & - & + & + & - & - & + & + & - & - & + & + \\
\hline 25 & - & - & - & + & - & - & + & + & - & - & + & + \\
\hline 26 & - & - & + & + & - & - & + & + & - & - & + & + \\
\hline 27 & - & NA & + & NA & - & - & + & - & - & - & + & + \\
\hline 28 & - & - & + & + & - & - & + & + & - & - & + & + \\
\hline 29 & - & - & + & + & - & - & + & + & - & - & + & + \\
\hline 30 & - & - & + & + & - & - & + & + & - & - & + & + \\
\hline 31 & - & - & + & + & - & - & + & + & - & - & + & + \\
\hline 32 & NA & NA & NA & NA & - & - & + & + & NA & - & NA & + \\
\hline 33 & NA & - & NA & + & NA & - & NA & + & NA & - & NA & + \\
\hline 34 & NA & - & NA & + & - & - & + & + & NA & - & NA & + \\
\hline 35 & - & + & + & + & - & - & + & + & - & - & + & $+\mathrm{v}$ \\
\hline 36 & - & - & + & + & - & - & + & + & - & - & + & + \\
\hline 37 & - & NA & + & NA & - & - & + & + & - & - & + & + \\
\hline 38 & NA & NA & NA & + & - & - & - & - & NA & - & NA & + \\
\hline 39 & - & - & + & + & - & - & + & + & - & - & + & + \\
\hline 40 & NA & NA & NA & NA & - & - & + & + & NA & - & NA & + \\
\hline 41 & NA & NA & NA & NA & - & - & + & + & NA & - & NA & + \\
\hline 42 & NA & - & NA & + & NA & - & NA & + & - & - & + & + \\
\hline 43 & NA & - & NA & - & - & - & - & - & NA & - & NA & + \\
\hline 44 & - & - & + & + & - & - & + & + & - & - & + & + \\
\hline 45 & NA & NA & NA & + & - & - & + & + & NA & - & NA & + \\
\hline
\end{tabular}

D: Donor, P: Patient, EA: Early antigen, EBNA: Epstein-Barr nuclear antigen, VCA: Viral capsid antigen, NA: Not available. 
donor and the recipient just before transplantation. However, this detection alone is not enough; the recipients should be followed regularly after the transplantation and tested in respect to possible viral infections [9]. The viral infections of the posttransplantation period may vary according to the type of the transplant. In patients with stem cell or bone marrow transplantation, polyoma, herpes simplex (HSV), and respiratory and enteric viral infections are common in the first month following the transplantation. In solid organ transplantation recipients, HSV infections are common in the first month following transplantation. In both groups, CMV, EBV, and varicella zoster virus infections may be seen after the second month. Periodic follow-up for viruses other than CMV is suggested in the posttransplantation period. However, no standardization has been provided yet [10].

The serological status of EBV in transplant recipients should be certain before the transplantation since seronegativity is a risk factor. Serology is limited since the severe immunosuppression of transplant recipients after the transplantation procedure inhibits the production of sufficient antibodies. Follow-up of the viral load by nucleic acid amplification tests is the preferred method [11]. Sometimes EBV may infect T/NK cells and cause persistent EBV infection. As a result, a high viral load and EBV-related T/NK cell lymphoproliferative disease follow. Therefore, the quantitation of EBV viral load is important, and the most common method used for this purpose is real-time PCR [12]. PCR-based tests are useful not only in prediction and diagnosis of PTLD, but also in monitoring the response to the treatment [13]. In ASCT patients with PTLD, EBV DNA load is generally higher than that of ASCT patients without PTLD. However, no consensus has been reached concerning which EBV DNA load threshold values cause high risk for EBV-related disease or PTLD development [14]. On the other hand, patients with immunodeficiency may not manifest EBV-related symptoms despite the detectable EBV DNA in their serum or plasma samples [15]. In our study, EBV-related symptoms or PTLD was not present in any of the patients who were detected to be positive for EBV DNA via real-time PCR. Agbalika et al. [16] mentioned that EBV EA-IgG presence in pre-ASCT patients increased the incidence of early PTLD development in the first year following transplantation. In this study, EBV DNA positivity was detected in 4 posttransplantation patients, and the positivity times were as follows: third month in 2 patients, fifth month in 1 patient, and sixth month in 1 patient. EAIgG was negative in $34(75.5 \%)$ patients and positive in 1 (2.2\%) patient. EA-IgG results could not be obtained in 10 cases (22.3\%). No EA-IgG positivity was detected before transplantation in any of the 4 patients with EBV DNA positivity.

PV B19 infections may be met in immunosuppression situations such as congenital or acquired immune deficiency syndrome, organ or bone marrow transplantation, lymphoproliferative disorders, malignancies, and chemotherapy [17]. In immunosuppressed patients, the clinical findings of PV B19 infection are severe, and viral eradication is late or inadequate. That may cause an aplastic crisis in patients with chronic hemolytic anemia [18].

Plentz et al. [19] detected PV B19 DNA in 21 (1\%) of 2123 tested blood samples that were going to be transplanted to patients with hematological cancer [18]. In the posttransplantation period of patients with ASCT, primary or recurrent PV B19 incidence is found to be 1\%-2\% when sensitive diagnostic methods are used [8,19]. As PV B19 cannot proliferate in continuous cell cultures and serological diagnosis is not reliable in immunosuppressed patients, viral particle- or viral DNA-detecting methods such as PCR and nucleic acid hybridization are needed for diagnosis [20,21]. Manaresi et al. [22] demonstrated that PV B19 DNA could be detected by PCR even if the samples were IgM- and IgGnegative. They also noted the importance of real-time PCR in laboratory diagnosis of PV B19 infections by pointing out that real-time PCR is 5-fold faster than PCR-ELISA and has a high specificity/sensitivity and low contamination risk, and quantitation is possible. Harder et al. [23] emphasized the usefulness of quantitation of viremia by real-time PCR in immunosuppressed, reinfected children for the planning of their treatment. In our study, no PV B19 DNA was detected in any of the posttransplantation patients, 44 of whom were detected to be PV IgM (-) and $\operatorname{IgG}(+)$, and 1 of whom was $\operatorname{IgM}(+)$ and $\operatorname{IgG}(-)$ before ASCT.

As a conclusion, in this study investigating EBV and PV B19 DNAs in ASCT patients, no PTLD development or PV B19 DNA positivity was observed. However, further prospective, multicenter studies with wider patient series should be conducted in order to better clarify the subject.

\section{Conflict of Interest Statement}

The authors of this paper have no conflicts of interest, including specific financial interests, relationships, and/ or affiliations relevant to the subject matter or materials included.

\section{References}

1. Rieger CT, Rieger H, Kolb HJ, Peterson L, Huppmann S, Fiegl $\mathrm{M}$, Ostermann H. Infectious complications after allogeneic stem cell transplantation: incidence in matched-related and matched-unrelated transplant settings. Transpl Infect Dis 2009;11:220-226.

2. Gratwohl A, Brand R, Frassoni F, Rocha V, Niederwieser D, Reusser P, Einsele H, Cordonnier C ;Acute and Chronic Leukemia Working Parties; Infectious Diseases Working Party of the European Group for Blood and Marrow Transplantation. Cause of death after allogeneic haematopoietic stem cell transplantation (HSCT) in early leukamias: an EBMT analysis of lethal infectious complications and changes over calender time. Bone Marrow Transplant 2005;36:757-769.

3. Fischer SA. Emerging viruses in transplantation: there is 
more to infection after transplant than CMV and EBV. Transplantation 2008;86:1327-1339.

4. Epstein MA, Crawford DH. Gammaherpesviruses: EpsteinBarr virus. In: Mahy BWJ, Volker TM (eds). Topley and Wilson's Microbiology and Microbial Infections, Virology Volume 1. 10th ed. London, UK, Hodder Education, 2005.

5. Wagner HJ, Rooney CM, Heslop HE. Diagnosis and treatment of posttransplantation lymphoproliferative disease after hematopoietic stem cell transplantation. Biol Blood Marrow Transplant 2002;8:1-8.

6. Zerbini M, Musiani M. Human parvoviruses. In: Murray PR, Baron EJ, Jorgensen JH, Pfaller MA, Yolken RH (eds). Manual of Clinical Microbiology. 8th ed. Washington, DC, USA, ASM Press, 2003.

7. Lackner H, Sovinz P, Benesch M, Aberle SW, Schwinger W, Schmidt S, Strenger V, Pliemitscher S, Urban C. The spectrum of parvovirus B19 infection in a pediatric hematooncologic ward. Pediatr Infect Dis J 2011;30:440-442.

8. Broliden K. Parvovirus B19 infection in pediatric solidorgan and bone marrow transplantation. Pediatr Transplant 2001:5:320-330.

9. Ljungman P. Risk assessment in haematopoietic stem cell transplantation: viral status. Best Pract Res Clin Haematol 2007;20:209-217.

10. Çolak D. Transplant alıcılarında virolojik ve immünolojik monitörizasyon. Ustaçelebi Ş, Abacıoğlu H, Badur S (eds). III. Ulusal Viroloji Kongresi, Konferanslar ve Bildiriler Kitabı. Ankara, Turkey, Öncü Basımevi, 2007 (in Turkish).

11. Rowe DT, Webber S, Schauer M, Reyes J, Green M. EpsteinBarr virus load monitoring: its role in the prevention and management of post-transplant lymphoproliferative disease. Transpl Infect Dis 2001;3:79-87.

12. Yamashita N, Kimura H, Morishima T. Virological aspects of Epstein-Barr virus infections. Acta Med Okayama 2005;59:239-246.

13. Wagner HJ, Rooney CM, Heslop HE. Diagnosis and treatment of posttransplantation lymphoproliferative disease after hematopoietic stem cell transplantation. Biol Blood Marrow Transplant 2002;8:1-8.

14. Styczynski J, Einsele H, Gil L, Ljungman P. Outcome of treatment of Epstein-Barr virus-related post-transplant lymphoproliferative disorder in hematopoietic stem cell recipients: a comprehensive review of reported cases. Transpl Infect Dis 2009;11;383-392.

15. Linde A. Epstein-Barr virus. In: Murray PR, Baron EJ, Jorgensen JH, Pfaller MA, Yolken RH (eds). Manual of Clinical Microbiology. 8th ed. Washington, DC, USA, ASM Press, 2003.

16. Agbalika F, Larghero J, Esperou H, Marais D, Robin M, Fois E, de Latour RP, Gluckman E, Rocha V, Benbunan M, Socie G, Marolleau JP. Epstein-Barr virus early-antigen antibodies before allogeneic haematopoietic stem cell transplantation as a marker of risk of post-transplant lymphoproliferative disorders. Br J Haematol 2007;136:305-308.

17. Kuo SH, Lin LI, Chang CJ, Liu YR, Lin KS, Cheng AL. Increased risk of parvovirus B19 infection in young adult cancer patients receiving multiple courses of chemotherapy. J Clin Microbiol 2002;40:3909-3912.

18. Plentz A, Hahn J, Knoll A, Holler E, Jilg W, Modrow S. Exposure of hematologic patients to parvovirus B19 as a contaminant of blood cell preparations and blood products. Transfusion 2005;45:1811-1815.

19. Hayes-Lattin B, Seipel TJ, Gatter K, Heinrich MC, Maziarz RT. Pure red cell aplasia associated with parvovirus B19 infection occurring late after allogeneic bone marrow transplantation. Am J Hematol 2004;75:142-145.

20. Yetgin S, Elmas SA. Parvovirus-B19 and hematologic disorders. Turk J Hematol 2010;27:224-233.

21. Cavallo R, Merlino C, Re D, Bolero C, Bergalla M, Lembo D, Musso T, Leonardi G, Segoloni GP, Ponzi AN. B19 virus infection in renal transplant recipients. J Clin Virol 2003;26:361-368.

22. Manaresi E, Gallinella G, Zuffi E, Bonvicini F, Zerbini M, Musiani M. Diagnosis and quantitative evaluation of parvovirus B19 infections by real-time PCR in the clinical laboratory. J Med Virol 2002;67:275-281.

23. Harder TC, Hufnagel M, Zahn K, Beutel K, Schmitt HJ, Ullmann U, Rautenberg P. New LightCycler PCR for rapid and sensitive quantification of parvovirus B19 DNA guides therapeutic decision-making in relapsing infections. J Clin Microbiol 2001;39:4413-4419. 